\title{
Effects of dietary mineral bioplex in pregnant and lactating sow diets on piglet performance and physiological characteristics
}

\author{
Antônio Gilberto Bertechini ${ }^{1}$, Edison José Fassani ${ }^{1}$, Jerônimo Ávito Gonçalves de Brito ${ }^{2}$, \\ Priscilla Rochele Barrios ${ }^{1}$
}

1 Universidade Federal de Lavras, Lavras, MG, Brazil, 37200-000.
2 Universidade Federal do Recôncavo da Bahia, Bahia, Brazil.

\begin{abstract}
A total of thirty-six Landrace $\times$ Large White sows were inseminated with semen of Large White boars and studied in late pregnancy (30 days pre-partum) and lactation phases to determine the effects of trace mineral supplementation in organic (bioplex) and inorganic forms at two levels of supplementation (1 and $2 \mathrm{~kg} / \mathrm{t})$ on the reproductive performance of the females and on piglet performance and physiologic characteristics until weaning at 21 days of age. The trace mineral supplements contained $0.0075 \%$ selenium, $2.50 \%$ zinc, $1.00 \%$ manganese, $4.00 \%$ iron, $0.25 \%$ copper and $0.01 \%$ chromium. The experimental design was completely randomized in a $2 \times 2$ factorial scheme with nine replicates each. The piglets were weighed at birth and at weaning (21 days) and were given a dose of $100 \mathrm{mg}$ of dextran iron on the third day of life. For performance, the mean measure of the litter, including both males and females, was considered. Blood and liver were collected from the piglets at birth (two per farrowing, one male and one female), and milk was collected 10 days thereafter. Increased weight at birth and at 21 days and increased iron content in the blood and liver were found for piglets when the sows were given the organic form of trace minerals. Increased iron content in the milk was observed for higher supplementation with organic minerals only. The blood iron levels indicated a significant increase in levels with the use of the organic minerals. These results indicate important benefits in using trace minerals in organic forms for the performance of both sows and piglets.
\end{abstract}

Key Words: iron nutrition, organic minerals, sow reproductive performance, trace minerals

\section{Introduction}

Research on the nutrition of gestating and lactating sows has been conducted with the purpose of improving the quality of piglets at birth as well as maintaining good nutritional status of sows throughout their reproductive lifespan. According to Mahan et al. (2009), during pregnancy, there is a large transfer of minerals from the sow to the fetus, indicating the need to increase supplementation during this phase to recover this depletion of, primarily, trace minerals.

The use of minerals in organic-complexed forms has been studied with this objective and also in relation to mineral excretion into the environment.

Trace mineral supplementation in swine diets follows the NRC recommendations (1998), in addition to indications recommended for individual genetic strains. There is generally no concern about the recommended mineral levels, i.e., the indications are similar for most of the developmental phases of pigs. However, there are difficulties at the level of absorption of microelements, leading to high levels of supplementation. These related aspects, along with the low costs of trace mineral supplementation in the diets, leads to the overuse of those nutrients, with significant impacts on the environment. The possibility of reducing trace mineral supplementation in diets using organic forms of minerals can improve the availability of the levels used, with greater responsibility in relation to excretions.

In gestating and lactating swine females, there is an issue of iron storage, a trace mineral of great importance, as evidenced by the low liver content in piglets at birth and associated with low levels in milk and the high early demand, resulting in iron-deficiency anemia, which critically affects the performance of the animals (Lee et al., 1998).

Research evaluating animal performance and absorption of organic minerals in the swine diet has been performed (Hill et al., 1987; Lindermann et al., 1995; Yu et al., 2000; Bertechini et al., 2005; Muniz et al., 2005; Peter and Mahan, 2005; Mahan et al., 2009; Peters et al., 2010).

The objective of this study was to evaluate the effects of diets with two levels of trace mineral supplementation (organic and inorganic forms) on the reproductive performance of reproductive sows in late pregnancy and lactation phases and on physiologic characteristics of piglets until weaning at 21 days of age. 


\section{Material and Methods}

The procedures and use of the animals in this experiment were approved by the Bioethical Committee in Utilization of Animals (protocol 14, 2010).

Thirty-six pregnant Landrace $\times$ Large White multiparous sows (parity $4.2 \pm 1.1$ ) were inseminated with sperm from Large White boars. In the last month of pregnancy, the sows were fed diets consisting of two trace mineral sources, inorganic (IM) and organic (OM), which contained iron, copper, zinc, manganese and selenium at two levels of supplementation in the $\operatorname{diet}(1 \mathrm{or} 2 \mathrm{~kg} / \mathrm{t})$ in a $2 \times 2$ factorial scheme (Table 1).

The experimental design was completely randomized, with four treatments, each with nine replicates. The animals were fed the experimental diets during late pregnancy (30 days pre-farrowing) through late lactation. The trace mineral supplements contained $0.0075 \%$ selenium, $2.50 \%$ zinc, $1.00 \%$ manganese, $4.00 \%$ iron, $0.25 \%$ copper and $0.01 \%$ chromium. The organic mineral sources were analyzed using atomic absorption (spectrophotometer model Varian Spectra A 2000), and the inorganic sources were prepared based on the analyzed composition of the organic source; the sources had the same composition. The inorganic source contained $\mathrm{Fe}$ as $\mathrm{FeSO}_{4}, \mathrm{Zn}$ as $\mathrm{ZnO}, \mathrm{Cu}$ as $\mathrm{CuSO}_{4}, \mathrm{Mn}$ as $\mathrm{MnSO}_{4}, \mathrm{Se}$ as $\mathrm{Na}_{2} \mathrm{SeO}_{3}$ and $\mathrm{Cr}$ as $\mathrm{CrCl}_{3}$.

The diets were formulated with corn and soybean meal according to the pregnancy and lactation phases (Table 2).

The organic material bioplex was analyzed with regard to the degree of trace mineral complexation through solubilization tests in acidic and basic media: the minerals that stayed in solution and those that remained in the organic matrix after ashing in a muffle furnace at $550^{\circ} \mathrm{C}$ were analyzed by atomic absorption (Varian Spectra A 2000). The selenium analyses were conducted using an atomic absorption spectrometer, equipped with a 77 VGA System for hydride generation and a $10 \mathrm{~mA}$ cathode lamp (Varian, Melbourne, Australia). Digestion was carried out in a

Table 1 - Trace mineral supplementation levels of organic and inorganic sources according to the level of supplementation

\begin{tabular}{|c|c|c|c|c|}
\hline \multirow{3}{*}{$\begin{array}{l}\text { Trace mineral } \\
\text { Level of use, } \mathrm{kg} / \mathrm{t}\end{array}$} & \multicolumn{4}{|c|}{ Treatment, ppm } \\
\hline & \multicolumn{2}{|c|}{ Inorganic source } & \multicolumn{2}{|c|}{ Organic source } \\
\hline & 1 & 2 & 1 & 2 \\
\hline Iron & 40 & 80 & 40 & 80 \\
\hline Copper & 2.5 & 5.0 & 2.5 & 5.0 \\
\hline Zinc & 25 & 50 & 25 & 50 \\
\hline Manganese & 10 & 20 & 10 & 20 \\
\hline Selenium & 0.075 & 0.150 & 0.075 & 0.150 \\
\hline Chromium & 0.100 & 0.200 & 0.100 & 0.200 \\
\hline
\end{tabular}

Table 2 - Basal diet composition used in the pregnancy and lactation phases (as-fed basis)

\begin{tabular}{lcc}
\hline Ingredients & Pregnancy & Lactation \\
\hline Corn & 71.80 & 59.80 \\
Soybean meal, 46\% & 12.00 & 29.00 \\
Wheat meal & 13.00 & 5.0 \\
Soybean oil & - & 3.0 \\
Dicalcium phosphate & 1.40 & 1.50 \\
Limestone & 0.90 & 0.80 \\
Iodized salt & 0.50 & 0.50 \\
Vitamin supplement ${ }^{1}$ & 0.10 & 0.10 \\
Inert (kaolin) & 0.30 & 0.30 \\
Calculated composition & & \\
ME, kcal/kg & 3090 & 3360 \\
CP, \% & 13.5 & 19.00 \\
CF, \% & 3.15 & 3.10 \\
Ca, \% & 0.75 & 0.79 \\
P, \% & 0.65 & 0.62 \\
Na, \% & 0.20 & 0.20 \\
Digestible lysine, \% & 0.50 & 0.87 \\
Digestible methionine, \% & 0.20 & 0.30 \\
Digestible threonine, \% & 0.42 & 0.62 \\
Digestible tryptophan, \% & 0.16 & 0.24 \\
\hline
\end{tabular}

ME - metabolizable energy; CP - crude protein; CF - crude fiber.

${ }^{1}$ Supplemented per kg of diet: vit. A - 10,000 UI; vit. D3 - 1,600 UI; vit. E $40 \mathrm{mg}$; vit. $\mathrm{K}_{3}-2.5 \mathrm{mg}$; vit. B 1 - $2.0 \mathrm{mg}$; vit. B2 - $4.0 \mathrm{mg}$; vit. B6 - $1.5 \mathrm{mg}$; vit B12 - $18.0 \mu \mathrm{g}$; Pantothenic acid - $15.0 \mathrm{mg}$; Niacin - $25.0 \mathrm{mg}$; Biotin, 0,2; Choline, $250.0 \mathrm{mg}$ and Folic acid, $0.8 \mathrm{mg}$.

digester oven for simple digestion (Merck Darmstadt, Germany). The results indicated the following complexed trace mineral composition: $\mathrm{Fe}-45.3 \%, \mathrm{Cu}-65.9 \%, \mathrm{Mn}-$ $30.1 \%, \mathrm{Zn}-28.3 \%$, Se $-35.5 \%$ and $\mathrm{Cr}-49.1 \%$. During the last 30 days of pregnancy, the feeding levels amounted to $2.5 \mathrm{~kg}$ per day, and water was available ad libitum. During this phase, the sows were housed individually in pregnancy crates $(0.6 \times 2 . \mathrm{m})$ on flat deck concrete. The temperature and relative humidity within the room were $25.5 \pm 1.2{ }^{\circ} \mathrm{C}$ and $60 \%$, respectively. During the lactation phase, the feed was offered ad libitum, and the animals had free access to water in a conch type drinker, and the average temperature and relative humidity were $24.2 \pm 1.5{ }^{\circ} \mathrm{C}$ and $68 \%$, respectively. The sows were kept in farrowing cages until weaning, when the piglets were 21 days old.

At the moment of farrowing, all of the piglets were weighed, and their ears were notched; one male and one female of each litter were used for blood and liver collection on the day of birth. Blood samples $(6 \mathrm{~mL})$ were collected by vena cava puncture from individual piglets into $10 \mathrm{~mL}$ evacuated and heparinized (143 units of sodium heparin) tubes for blood analyses. The blood samples were analyzed for hematocrit, hemoglobin, global leukocyte, red blood cells, mean corpuscular volume, mean hemoglobin volume, mean corpuscular hemoglobin concentration, and platelets. After collection, the blood samples were packed in plastic foam boxes containing biologic ice. A replicate of the blood 
with no anticoagulant was collected and stored at room temperature for serum collection. At the end of the collections, all the material was immediately transported to the Veterinary Medicine Department Clinic Pathology Laboratory of the Universidade Federal de Lavras, where they were processed on the same day of collection. For obtaining the serum, the samples were kept in a water bath at $37^{\circ} \mathrm{C}$ for 20 minutes and then centrifuged at $3,000 \mathrm{rpm}$ for ten minutes. The serum was frozen after separation at $-20^{\circ} \mathrm{C}$ until analysis. An electronic counter was used to obtain the hematological parameters (model Coulter Micro Diff II).

After blood collection, the piglets were slaughtered following the recommended (BRASIL - MAPA) slaughter regulations for the removal of the livers for analysis of hepatic total trace minerals at birth. After removal, the livers were weighed and packed in plastic bags and stored at $-20^{\circ} \mathrm{C}$ until analysis. The livers were thawed at room temperature, and approximately $1 \mathrm{~g}$ of each liver, removed from the 4 th quadrant of the right lobe, was digested with $\mathrm{HNO}_{3}\left(\mathrm{Merck}^{\circledR}\right.$ P.A.). The concentration of iron in the sample was determined using the atomic absorption spectrophotometry method according to the AOAC (1990).

On the farrowing and tenth days, the milk from sows milk was collected for analyses of the trace minerals using nitroperchloric digestion and atomic absorption spectrophotometry.

Only the values determined for iron are presented here due to their importance for piglets.

The piglets were weighed at birth and at weaning (21 days) and were given a dose of $100 \mathrm{mg}$ dextran iron $(1 \mathrm{~mL})$ on the third day after birth. The results of piglet performance are provided as the mean of male and females.

The experiment was conducted according to a $2 \times 2$ factorial arrangement: two mineral-trace source supplements, organic and inorganic, with two levels of supplementation, $1 \mathrm{~kg} / \mathrm{t}$ and $2 \mathrm{~kg} / \mathrm{t}$, with 9 replicates per treatment. The model consisted of forms of mineral-trace supplementation, level of supplementation, interaction between both and effect on the animals. The data were analyzed using the SAS computational package (Statistical
Analysis System, version 8.2) and were subjected to an analysis of variance using the Tukey test at a $5 \%$ level of significance for the comparison of all of the joint treatments.

\section{Results and Discussion}

The number of piglets born alive was affected $(\mathrm{P}<0.05)$ only because the use of the organic mineral at the $2 \mathrm{~kg} / \mathrm{t}$ level resulted in a greater number of piglets born $(\mathrm{P}<0.05)$, and the other nonsignificant differences $(\mathrm{P}>0.05)$ were observed (Table 3 ). The birth and weaning weights of the piglets were higher for the sows fed the diets containing organic minerals $(\mathrm{P}<0.05)$. There were no effects of the levels of trace minerals $(\mathrm{P}>0.05)$ in organic or inorganic form on the weight of the piglets at birth. Concerning the weaning weight, better results $(\mathrm{P}<0.05)$ were found for the organic minerals, regardless of the level of supplementation of the trace minerals. However, for the inorganic source, the highest supplementation $(2 \mathrm{~kg} / \mathrm{t})$ resulted in increased weights $(\mathrm{P}<0.05)$ at weaning, compared to the supplementation of $1 \mathrm{~kg} / \mathrm{t}$.

The results observed for the weights of the piglets at birth and weaning indicated that those born to the sows fed the diet containing trace minerals in the organic form presented increased birth and weaning weights. Effects of treatments of organic minerals on piglet birth and weaning weights were also evaluated by Peters \& Mahan (2005). In that study, it was also found that the litters were heavier and that there were greater weight gains until weaning using diets with organic trace minerals. However, it was also observed that the sows fed diets with organic trace minerals farrowed a greater number of piglets, which was not found in the present study, except for the treatment with $2 \mathrm{~kg} / \mathrm{t}$ of organic trace minerals. Furthermore, in the study of Peters and Mahan (2005), the sows were fed a diet with organic minerals beginning at $30 \mathrm{~kg}$, and the evaluation ended when the animals reached the fourth partum. The influence of trace minerals on mammals is well described with regard to aspects of reproductive efficiency (Hostetler et al., 2003). The best efficiency of organic trace minerals on the

Table 3 - Reproductive performance measurements of sows fed dietary trace mineral sources and levels

\begin{tabular}{|c|c|c|c|c|c|}
\hline \multirow{3}{*}{ Items* } & \multicolumn{4}{|c|}{ Mineral sources and levels } & \multirow{3}{*}{$\mathrm{CV} \%$} \\
\hline & \multirow{2}{*}{$\begin{array}{c}\mathrm{IM} \\
1 \mathrm{~kg} / \mathrm{t}\end{array}$} & \multicolumn{3}{|c|}{$\mathrm{OM}$} & \\
\hline & & $2 \mathrm{~kg} / \mathrm{t}$ & $1 \mathrm{~kg} / \mathrm{t}$ & $2 \mathrm{~kg} / \mathrm{t}$ & \\
\hline Weight at birth (g) & $1496 b$ & $1516 b$ & $1636 \mathrm{a}$ & $1677 \mathrm{a}$ & 6.9 \\
\hline Weight at $21 \mathrm{~d}(\mathrm{~g})$ & $6176 c$ & $6915 b$ & $7639 a$ & $7832 \mathrm{a}$ & 5.2 \\
\hline
\end{tabular}

*IM - inorganic mineral; OM - organic mineral.

*Numbers in rows followed by different letters represent differences $(\mathrm{P}<0.05)$ by Tukey test 
reproductive efficiency of sows was evaluated by finding the best conception rate (Mirando et al., 1993) and the best embryonic mass at 15 days of pregnancy (Hostetler and Mirando, 1998). Nevertheless, in the present study, the organic minerals were included during the last 30 days of pregnancy, and an effect on the number of piglets born was only found with the use of the $2 \mathrm{~kg} / \mathrm{t}$ dose.

There were significant differences $(\mathrm{P}<0.05)$ in the iron contents of the livers and blood of newborn piglets fed inorganic versus organic minerals (Table 4). For the liver, the highest values were obtained for the offspring of the sows fed the organic trace minerals and the highest supplementation level of the inorganic form $(\mathrm{P}<0.05)$. However, for the blood iron content, the highest value $(\mathrm{P}<0.05)$ was found for the organic source, regardless of the level. Within each source, the levels did not influence the blood iron contents $(\mathrm{P}>0.05)$. The results also indicated that the $1 \mathrm{~kg} / \mathrm{t}$ OM resulted in greater contents of iron in the blood of the newborn piglets, even when the levels of supplementary iron was lower than the $2 \mathrm{~kg} / \mathrm{t} \mathrm{IM} \mathrm{level.} \mathrm{It}$ was also found that the highest iron contents in milk were in the animals subjected to $2 \mathrm{~kg} / \mathrm{tOM}(\mathrm{P}<0.05)$. The statistical analysis also indicated that, despite increasing the blood iron content, the use of $1 \mathrm{~kg} / \mathrm{t} \mathrm{OM}$ did not result in higher iron deposition, stressing the difficulty in this transfer.
Regarding the blood that was collected from the newborn piglets, no significant differences $(\mathrm{P}>0.05)$ were found for the global leukocytes, red cell count or medium corpuscular hemoglobin concentration (Table 5). However, significant differences $(\mathrm{P}<0.05)$ in the hematocrit values were noted, with the highest for the offspring of the sows subjected to the $1 \mathrm{~kg} / \mathrm{t}$ and $2 \mathrm{~kg} / \mathrm{t} \mathrm{OM}$ treatments, compared with $1 \mathrm{~kg} / \mathrm{t} \operatorname{IM}(\mathrm{P}=0.03)$. This difference was not observed between the $2 \mathrm{~kg} / \mathrm{t}$ IM and the other level of the organic source. The $2 \mathrm{~kg} / \mathrm{t} \mathrm{OM}$ treatment increased the hemoglobin compared to the other treatments $(\mathrm{P}=0.001)$.

The mean corpuscular volume values were lower for the $1 \mathrm{~kg} / \mathrm{t}$ IM $(\mathrm{P}<0.05)$, and the lowest supplementations, both in the organic and inorganic form, presented similar mean corpuscular volume values $(\mathrm{P}>0.05)$.

For the mean hemoglobin volume values, the use of $1 \mathrm{~kg} / \mathrm{t} \mathrm{OM}$ and $2 \mathrm{~kg} / \mathrm{t} \mathrm{IM}$ resulted in values higher than for $1 \mathrm{~kg} / \mathrm{t} \mathrm{IM}(\mathrm{P}=0.0089)$, that is, $2 \mathrm{~kg} / \mathrm{t} \mathrm{OM}$ did not differ from the others $(\mathrm{P}>0.05)$. There were also increased platelets counts for the animals subjected to the treatment with organic minerals $(\mathrm{P}=0.0093)$, compared with $1 \mathrm{~kg} / \mathrm{t} \mathrm{IM}$. The treatment with $2 \mathrm{~kg} / \mathrm{t}$ IM did not differ from the others $(\mathrm{P}>0.05)$ for the platelet count, yet differences $(\mathrm{P}<0.05)$ were found for the inclusion of the organic trace minerals, resulting in higher values.

Table 4 - Iron content in tissues according to mineral source and levels

\begin{tabular}{|c|c|c|c|c|c|}
\hline \multirow{3}{*}{ Item* } & \multicolumn{4}{|c|}{ Mineral source and levels } & \multirow[t]{3}{*}{$\mathrm{CV} \%$} \\
\hline & \multicolumn{2}{|c|}{ IM } & \multicolumn{2}{|c|}{$\mathrm{OM}$} & \\
\hline & $1 \mathrm{~kg} / \mathrm{t}$ & $2 \mathrm{~kg} / \mathrm{t}$ & $1 \mathrm{~kg} / \mathrm{t}$ & $2 \mathrm{~kg} / \mathrm{t}$ & \\
\hline No. of piglets & 18 & 18 & 18 & 18 & \\
\hline Liver, $\mathrm{mg} / \mathrm{kg}$ & $1638 b$ & $1779 \mathrm{ab}$ & $1897 \mathrm{a}$ & $2171 \mathrm{a}$ & 20.3 \\
\hline Blood, $\mu \mathrm{g} / \mathrm{dL}$ & $147.7 b$ & $173.7 b$ & $211.2 \mathrm{a}$ & $227.8 \mathrm{a}$ & 18.0 \\
\hline No. of sows & 9 & 9 & 9 & 9 & \\
\hline
\end{tabular}

*IM - inorganic mineral; OM - organic mineral.

*Numbers in the same row followed by different letters represent differences $(\mathrm{P}<0.05)$ by Tukey test.

Table 5 - Hematocrit, hemoglobin, global leucocytes, red cell count, mean corpuscular volume (MCV), mean hemoglobin volume (MHV), mean corpuscular hemoglobin concentration (MCHC) and platelet count of newborn piglet blood according to mineral sources and levels

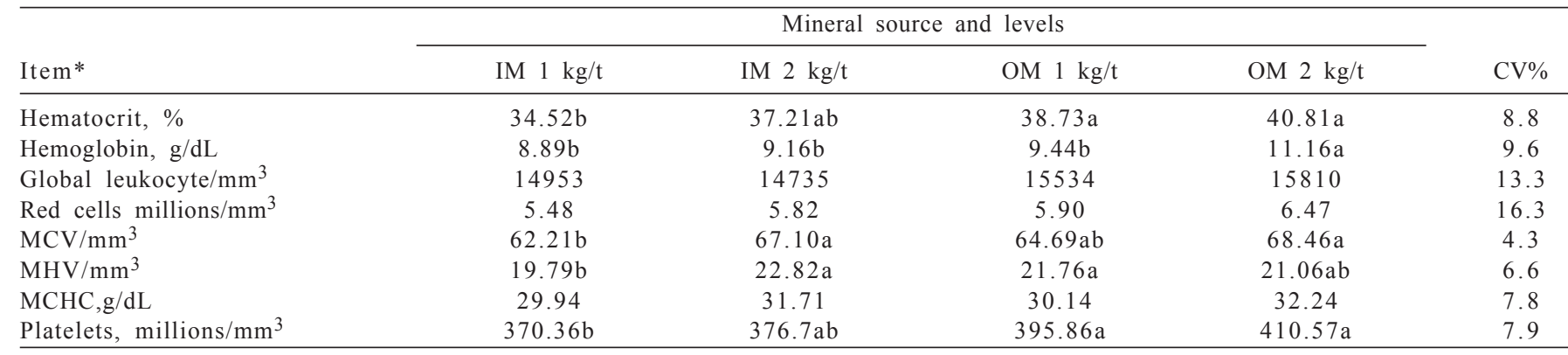

*Numbers in the same rows followed by different letters represent differences $(\mathrm{P}<0.05)$ by Tukey test. 
The effect of organic selenium was also evaluated by Mahan and Kim (1996). The authors observed that gilts treated with organic selenium farrowed piglets with increased amounts of serum, hepatic and muscular selenium but with no effect on the number and weight of piglets born. An increase in serum selenium was also found in the sows and milk, indicating a greater absorption and transplacental passage and transfer into the milk of the organic form of the mineral. However, the differences between the sources of selenium had no contribution to the differences in birth and weaning weights.

For copper and zinc, Lee et al. (2001) observed a higher amount of serum copper and zinc and lower amounts excreted in the feces of animals treated with those elements in the organic form, showing greater absorption of organic sources of those minerals. Considering the effect of copper on bone development and growth, of zinc on gene expression, appetite and function of zinc metalloenzymes, and of manganese on the development of cartilage and the metabolism of lipids and carbohydrates (Underwood, 1999), an improved bioavailability of these minerals could be responsible for the better performance of the sows fed the organic trace minerals. Further studies are necessary to verify the transplacental passage and milk transfer of these elements and the possible contribution of each element in the obtained results.

The results demonstrated also that organic mineralfed females gave birth to piglets with higher hepatic and blood iron contents, compared to the animals that were fed diets containing inorganic trace minerals, and those values did not depend on the supplementation level. Placental iron transfer was investigated by Douglas et al. (1972) who found that, when ferric citrate was injected into sows, a slight increase in the iron content in the fetal tissues (heart, kidneys, pancreas and liver) at 14 days after application was observed, with the liver showing the greatest increase of $0.533 \%$ of the dose applied. In the placenta, however, there was greater iron deposition, $1.3 \%$, and the presence of transferrin and placental transferrin was also demonstrated. It was found that there is an increase of iron in the fetal tissues in response to iron supplementation in sows; nevertheless, placental transfer is limited. The increase in the iron content found in the liver of the piglets and blood of the OM-treated sows indicates that there was increased transplacental passage of the iron. Other studies have demonstrated that the best absorption of iron occurs with the organic form (Yu et al., 2000; Muniz et al., 2005; Bertechini et al., 2005). Nevertheless, the mechanisms of mineral absorption in the intestine and the placental transfer to piglets require specific studies.

Regarding the iron contents in milk, the $2 \mathrm{~kg} / \mathrm{t} \mathrm{OM}$ treatment promoted higher values $(\mathrm{P}<0.05)$. Despite the supplementation of different doses of iron, there were no differences in the iron excreted in milk with $1 \mathrm{~kg} / \mathrm{t}$ and $2 \mathrm{~kg} / \mathrm{t} \mathrm{IM}$. Similarly, the results with $1 \mathrm{~kg} / \mathrm{t} \mathrm{OM}$ did not differ from $1 \mathrm{~kg} / \mathrm{t} \mathrm{IM}$, demonstrating that, at low doses, the organic minerals did increase the levels of iron in the milk. The iron levels in the colostra and milk was also evaluated by Csapó et al. (1996), who found that the iron levels are lower on the farrowing day $(1.70 \mathrm{mg} / \mathrm{kg})$ and reach a peak on the third day after partum $(2.92 \mathrm{mg} / \mathrm{kg})$; thereafter, the levels remain between 2.02 and $2.44 \mathrm{mg} / \mathrm{kg}$ until 60 days after farrowing. The analysis of the iron collected on the day after partum reflect an iron content between the basal and peak levels. The transfer of plasma iron to milk occurs initially via transferrin receptors (TfR) located in the secretory epithelial cells in the mammary gland. Transferrin binds to TfR and enters the cell where it merges with endosomes. The acidic medium facilitates iron release from the transferrin-TfR complex, and the transfer of iron is facilitated by divaltent1 metal transporter (DMT1). Inside the cell, iron functions in a number of processes or is exported to the milk. The transfer of iron to milk occurs through ferroportin (FNP), located in the endoplasmic reticulum, which facilitates the transport of intracellular iron within vesicles. In situations of iron deficiency in women and mice, in spite of the reduction of ferritin storage in the glandular mammary tissue, the levels of iron excreted in the milk are not affected (Kelleher and Lönnerdal, 2005). Much of the iron in milk is bound to lactoferrin (Lönnerdal et al., 1976). It is possible that the high iron content resulting from feeding the organic minerals had influenced the levels of serum transferrin and, thus, the iron content contained in the colostra. Nevertheless, further studies are necessary to confirm this hypothesis.

Although the blood iron was higher for the organic mineral treatment (Table 4), indicating an increased transplacental passage of iron, only $1 \mathrm{~kg} / \mathrm{t}$ IM displayed hematocrit differences relative to the treatments with organic minerals; the $2 \mathrm{~kg} / \mathrm{t} \mathrm{IM}$ treatment did not differ from the other treatments, reflecting differences in the iron available for the piglets. The $2 \mathrm{~kg} / \mathrm{t} \mathrm{OM}$ treatment differed from the others with regard to the hemoglobin results; thus, one can conclude that $2 \mathrm{~kg} / \mathrm{t}$ OM provided a larger amount of iron available for the piglets for the formation of red cells.

Statistical analysis showed no differences in the hemoglobin values for the $1 \mathrm{~kg} / \mathrm{t} \mathrm{OM}, 1 \mathrm{~kg} / \mathrm{t} \mathrm{IM}$ and $2 \mathrm{~kg} / \mathrm{t}$ IM treatments; the mean corpuscular volume result 
decreased under $1 \mathrm{~kg} / \mathrm{t} \mathrm{IM}$ in comparison to $2 \mathrm{~kg} / \mathrm{t} \mathrm{IM}$ and $2 \mathrm{~kg} / \mathrm{t} \mathrm{OM}$, indicating that there was an inadequate concentration of hemoglobin due to iron deficiency and increased cell division, with decreases in the mean corpuscular volume value. This observation was confirmed by the low mean hemoglobin volume under $1 \mathrm{~kg} / \mathrm{t} \mathrm{IM}$, differences that were not found for the $\mathrm{MCHC}$ values due to the smaller size of the cells. The use of the organic mineral $(\mathrm{OM})$ source increased the platelet level $(\mathrm{P}<0.05)$. Because these cells are related to blood clotting, the observed increase can explain the better recovery of lesions caused by pathogens, ensuring a better intestinal integrity, which is important for newborn and young animals. Platelets act on primary homeostasis and blood clotting (Lorenzi et al., 2003). Immunologic complexes can interact with platelets via receptors, leading to the aggregation and formation of microthrombi, increasing the vascular impermeability by the release of vasoactive amines. Platelets are important sources of growth factors, and the release of these factors contributes to cell proliferation (Roitt et al., 1993).

\section{Conclusions}

The use of an organic form of trace minerals results in increased birth and weaning weights of piglets, compared to an inorganic source. Piglets from sows treated with minerals in the organic form are born with higher contents of blood iron and a larger hepatic iron reserve. The organic mineral-treated sows excrete larger amount of iron in their milk.

\section{References}

ASSOCIATION OF OFFICIAL ANALYTICAL CHEMISTRY OAC. Official methods of analysis. 15.ed. Arlington: AOAC International, 1990. $1230 \mathrm{p}$.

BERTECHINI, A.G.; COELHO, A.C; NETO, J.V. et al. Utilização de minerais orgânicos na absorção de ferro em suínos na fase de crescimento. In: CONGRESSO BRASILEIRO DE VETERINÁRIOS ESPECIALISTAS EM SUÍNOS, 12., 2005, Fortaleza. Proceedings... Fortaleza, 2005. p.444.

CSAPÓ, J.; MARTIN, T.G.; CSAPÓ-KISS, Z.S. et al. Protein, fats, vitamin and mineral concentration in porcine colostrums and milk from parturition to 60 days. International Dairy Journal, v.6, n.3, p.881-902, 1996.

DOUGLAS, T.A.; RENT, J.P. ; WATTS, C. et al. Placental transfer of iron in the sow (Sus domesticus). Compendium Biochemistry Phisiology, v.43A, p.665-671,1972.

HILL, D.A.; PEO, E.R.; LEWIS, A.J. Effect of zinc source and picolinat acid on $\mathrm{Zn}$ uptake in an in vitro continous-flow perfusion system for pig and poultry intestinal segments. Journal of Nutrition, v.117, p.1704-1707, 1987.
HOSTETLER, C.E.; KINCAID, R.L.; MIRANDO, M.A. The role of essential trace elements in embryonic and fetal development in livestock. The Veterinary Journal, v.166, n.1, p.125-139, 2003.

HOSTETLER, C.E.; MIRANDO, M.A. Dietary supplementation of proteinated trace minerals influences reproductive and growth performance of replacement gilts. Journal of Animal Science, v.76 (Suppl.1), p.274, 1998.

KELLEHAER, S.L.; LÖNNERDAL, B. Molecular regulation of milk trace mineral homeostasis. Molecular Aspects of Medicine, v.26, n.2, p. 328-339, 2005

LEE, S.H.; CHOI, S.C.; CHAE, B.J. et al. Evaluation of metalamino acid chelates and complexes at various levels of copper and zinc in weanling pigs and broiler chicks. Asian-Australian Journal of Animal Science, v.14, p.734-1740, 2001.

LINDERMANN, M.D.; WOOD, C.M.; HARPER, A.F. et al. Dietary chromium picolinate additions improve gain:feed and carcass characteristics in growing-finishing pigs and increased litter size in reproducing sows. Journal of Animal Science, v.73, n.3, p.457-465, 1995.

LÖNNERDAL, B.; FORSEUM, E.; HAMBRACEUS, L.A. A longitudinal study of the protein nitrogen, and lactose concentrations of human milk from Swedish well-nourished mothers. American Journal Clinical Nutrition, v.29, n.10, p.1127-1133, 1976.

LORENZI, F.T.; D'AMICO, E.; DANIEL, M.M. et al. Manual de hematologia propedeudica e clínica. 3.ed. Rio de Janeiro: Medsi, 2003. 665p.

MAHAN, D.C.; NEWT, E.A. Effect of initial breeding weight on macro and trace mineral composition over a three parity period using a high-producing sow genotype. Journal of Animal Science, v.73, n.1, p.51-158, 1995

MAHAN, D.C.; KIM, YY. Effect of inorganic or organic selenium at two dietary levels on reproductive performance and tissue selenium concentrations in first-parity gilts and their progeny. Journal of Animal Science, v.74, n.10, p.2711-2718, 1996.

MAHAN, D.C.; WATTS, M.R.; ST-PIERRE, N. Macro and trace mineral composition of fetal pigs and their accretion rates during fetal development. Journal of Animal Science, v.87, n.12, p.2823-2832, 2009.

MIRANDO, M.A.; PETERS, D.N.; HOSTETLER, C.E. et al. Dietary supplementation of proteinated trace minerals influences reproductive performance of sows. Journal of Animal Science, v.71 (suppl 1), p.358, 1993.

MUNIZ, M.; BERTO, D.; WECHSLER, F. et al. Chelated minerals in diets for weanned piglets. Journal of Animal Science, v.83, (suppl. 2), p.178, 2005

NATIONAL RESEARCH COUNCIL - NRC. Nutrient requirements of swine. 10.ed. Washington: National Academy Press, 1998 $212 \mathrm{p}$.

PETERS, J.C.; MAHAN, D.C. Effects of dietary organic and inorganic trace minerals at NRC or elevated levels on sow reproductive performance over four parities. Journal of Animal Science, v.83, (suppl. 2), p.204, 2005.

PETERS, J.C.; MAHAN, D.C.; WISEMAN, T.G. et al. Effect of dietary organic and inorganic micromineral source and level on sow body, liver, colostrum, mature milk, and progeny mineral compositions over six parities. Journal of Animal Science, v.88, n.2, p.626-637, 2010.

ROITT, I.; BROSTOFF, J.E.; DAVID, M. Imunologia. 3.ed. São Paulo: Manole, 1993. 1954p.

UNDERWOOD, E.J.; SUTTLE, N.F. The mineral nutrition of livestock. Wallingford: CABI, 1999. 602p.

YU, B.; HUANG, W.; CHIOU, P.W. Bioavailability of iron from amino acid complex in weanling pigs. Animal Feed Science and Technology, v.86, n.1, p.9-52, 2000. 